\title{
両端の固定度を考慮した座屈補剛 H 形鋼ブレースの耐力 STRENGTH OF H-SHAPED BRACE CONSTRAINED FLEXURAL BUCKLING IN CONSIDERATION OF BOUNDARY CONDITION AT BOTH ENDS
}

\author{
宇佐美 徹*，金子洋 文**，小野徹 郎*** \\ Tetsu USAMI, Hirofumi KANEKO and Tetsuro ONO
}

\begin{abstract}
The brace installed in frame has various boundary conditions, for example, simple supported, fixed or semirigid end , at both ends. This paper evaluates the strength of $\mathrm{H}$-shaped brace constrained flexural buckling, taking these boundary conditions into consideration. Boundary conditions were considered as rotational rigidity and strength was evaluated about three failure modes, respectively. And the propriety of it was verified by structural experiments. By this evaluation, the rotational rigidity which can be regarded as a simple supported end or a fixed end had been grasped. Moreover, one example of the rotational rigidity evaluation about actual structure details was shown.
\end{abstract}

Keywords: H-Shaped brace constrained flexural buckling, Static loading test, Strength evaluation, Boundary condition 座屈補剛 $\mathrm{H}$ 形鋼ブレ一ス、静的載荷実験、耐力評価、境界条件

1. はじめに

細長比の大きな鉄骨ブレースは圧縮力を受けると曲げ座屈変形を 生ずる。この座屈変形を鋼管などで拘束したブレースは座屈補剛ブ レースと呼ばれ、細長比の大きな場合にも耐力を発揮できる。

一般的に座屈補剛ブレースは端部に無補剛区間がない、あるいは 非常に短い場合が多いが、本報で対象とする座屈補剛ブレースは、 施工性を考慮して両端に無補剛区間を有することを特徵とするもの で、H 形鋼をブレース心材として鋼管で曲げ座屈補剛を行うもので ある。筆者らは、これまでこの座屈補剛ブレースについて、両端単 純支持と両端固定支持に対する耐力評価式を導き、実験によりその 妥当性を示した ${ }^{12,2) 。 ~}$

鉄骨ブレースを架構に組み込んで設計する場合、ブレ一ス端部の 詳細に従って単純支持あるいは固定支持としている。しかしなが ら、実際のブレース端部詳細は完全に単純支持や固定支持と見なせ る訳ではなく、安全側の判断として境界条件の評価を行っているの が現状である。当該座屈補剛ブレースは、両端単純支持の場合、両 端無補剛区間のブレース心材断面を補強しないとブレース心材中央 の軸降伏耐力を確保できないが ${ }^{1}$ 、両端固定支持の場合、端部の補 強がなくても軸降伏耐力を確保することができる2。そのため、ブ レース端部固定度が不明で、境界条件を単純支持と評価した場合
は、ブレース心材端部無補剛区間を補強した設計となる。

座屈長さに対する境界条件の影響を検討した研究等に見られるよ うに、端部の境界条件が完全に固定支持でなくとも、ある程度の固 定度を有すれば固定支持と同様の座屈長さと見なせることが解って いる。同様に、当該座屈補剛ブレースでも固定支持と同等と見なせ る固定度を把握することにより、ブレースを両端固定支持として取 り扱え、合理的な設計が可能になると考えられる。

本報では、端部に無補剛区間を有する座屈補剛ブレースの端部固 定度をパラメータとした構造実験を行い、その端部固定度が耐力に 与える影響を把握するとともに、本報で提案する耐力評価式の妥当 性を示す。また、両端単純支持あるいは両端固定支持と考えられる 固定度の検討を行うとともに、実建物の端部固定度の評価の一例を 示す。

2. 耐力評価手法

2.1 釣り合い式

モデルは、図 1 に示す一波の変形で耐力が決まる座屈補剛ブ レースとする。ブレース心材と座屈補剛材は連続材としてたわみ 変形すると仮定し、座屈補剛ブレースを連続する三変断面材と してモデル化する。初期たわみ $0 y$ を有し、座屈補剛材のたわみ
* 竹中工務店技術研究所 研究主任 $\cdot$ 工修

** 竹中工務店技術研究所 主席研究員 - 工博

*** 名古屋工業大学建築・デザイン工学科 教授・工博
Assoc. Chief Researcher, R\&D Inst., Takenaka Corp., M. Eng.

Senior Chief Researcher, R\&D Inst., Takenaka Co., Dr. Eng.

Prof., Dept. of Architecture, Nagoya Inst. of Tech., Dr. Eng. 
を ${ }_{s} y$ 、ブレース端部のたわみを ${ }_{b} y_{l},{ }_{b} y_{r}$ 、軸方向作用荷重を $P$ とすると、つり合い方程式は次式で与えられる。なお、初期たわ み ${ }_{0} y$ はブレース心材の初期たわみに座屈補剛材とブレース心材 とのクリアランスを加えたものである。

$$
\begin{array}{lc}
\frac{d^{2}}{d x^{2}}\left({ }_{b} E_{l{ }_{b}} I_{l} \frac{d^{2}{ }_{b} y_{l}}{d x^{2}}\right)+P \cdot\left(\frac{d^{2}{ }_{b} y_{l}}{d x^{2}}+\frac{d^{2}{ }_{0} y}{d x^{2}}\right)=0 & \left(-\frac{\ell}{2} \leq x \leq \ell_{1 l}\right) \\
\frac{d^{2}}{d x^{2}}\left({ }_{s} E_{s} I \frac{d^{2}{ }_{s} y}{d x^{2}}\right)+P \cdot\left(\frac{d^{2}{ }_{s} y}{d x^{2}}+\frac{d^{2}{ }_{0} y}{d x^{2}}\right)=0 & \left(-\ell_{1 l} \leq x \leq \ell_{1 r}\right) \\
\frac{d^{2}}{d x^{2}}\left({ }_{b} E_{r}{ }_{b} I_{r} \frac{d^{2}{ }_{b} y_{r}}{d x^{2}}\right)+P \cdot\left(\frac{d^{2}{ }_{b} y_{r}}{d x^{2}}+\frac{d^{2}{ }_{0} y}{d x^{2}}\right)=0 & \left(\ell_{1 r} \leq x \leq \frac{\ell}{2}\right)
\end{array}
$$$$
(1 \mathrm{a}, 1 \mathrm{~b}, 1 \mathrm{c})
$$

ここに、 $E_{s} \cdot{ }_{s} I:$ 座屈補剛材の曲げ剛性

${ }_{b} E_{l} \dot{b}_{b} I_{l},{ }_{b} E_{r} \dot{b}_{b} I_{r}:$ 両端のブレース心材端部無補剛区間の曲 げ剛性

$\ell:$ ブレース材長

$\ell_{11} 、 \ell_{1 r}:$ ブレースの中央からの補剛区間長さ

(1) 式の一般解は $C_{1} \sim C_{15}$ を積分定数として次式で表される。

${ }_{b} y_{l}=C_{1} \cdot \sin \left({ }_{b} \alpha_{l} \cdot x\right)+C_{2} \cdot \cos \left({ }_{b} \alpha_{l} \cdot x\right)+C_{3} \cdot x+C_{4}+C_{5}{ }_{0} y$

${ }_{s} y=C_{6} \cdot \sin \left({ }_{s} \alpha \cdot x\right)+C_{7} \cdot \cos \left({ }_{s} \alpha \cdot x\right)+C_{8} \cdot x+C_{9}+C_{10}{ }_{0} y$

${ }_{b} y_{r}=C_{11} \cdot \sin \left({ }_{b} \alpha \cdot x\right)+C_{12} \cdot \cos \left({ }_{b} \alpha_{r} \cdot x\right)+C_{13} \cdot x+C_{14}+C_{15} \cdot{ }_{0} y$

$(2 \mathrm{a}, 2 \mathrm{~b}, 2 \mathrm{c})$

ここに、, ${ }_{b} \alpha_{l}=\sqrt{\frac{P}{{ }_{b} E_{l}{ }_{b} I_{l}}},{ }_{s} \alpha=\sqrt{\frac{P}{{ }_{s} E_{s} I}},{ }_{b} \alpha_{r}=\sqrt{\frac{P}{{ }_{b} E_{r}{ }_{b} I_{r}}}$

$(3 a, 3 b, 3 c)$

一次モードの変形に対し、初期たわみは最大值が $a_{0}$ となる一波 の次式を用いる。

$$
{ }_{0} y=a_{0} \cos \left(\frac{\pi}{\ell} x\right)
$$

（1）、（2）式と境界条件、連続条件を用いて積分定数を求める。端 部の固定度は回転剛性として表現した。

$$
\begin{aligned}
& \left.{ }_{b} y_{l}\right|_{x=-\frac{\ell}{2}}=\left.0 、{ }_{b} E_{l} \dot{b}_{b} I_{l} \frac{d^{2}{ }_{b} y_{l}}{d x^{2}}\right|_{x=-\frac{\ell}{2}}+\left.K_{l} \frac{d_{b} y_{l}}{d x}\right|_{x=-\frac{\ell}{2}}=0 \\
& \left.{ }_{b} y_{r}\right|_{x=\frac{\ell}{2}}=\left.0 、{ }_{b} E_{r} \dot{b}_{b} I_{r} \frac{d^{2}{ }_{b} y_{r}}{d x^{2}}\right|_{x=\frac{\ell}{2}}+\left.K_{r} \frac{d_{b} y_{r}}{d x}\right|_{x=\frac{\ell}{2}}=0
\end{aligned}
$$

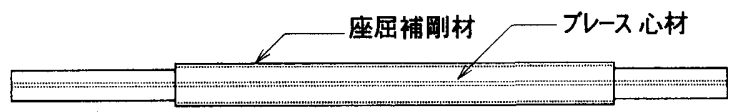

無補剛区間」補剛区間 無補剛区間

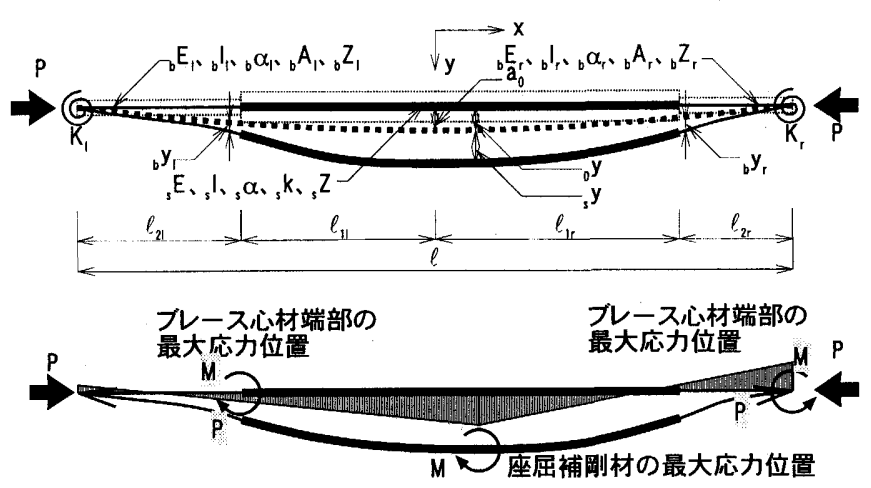

図 1 耐力評価モデル

$$
\begin{aligned}
& \left.{ }_{s} y\right|_{x=-\ell_{11}}-\left.{ }_{b} y_{l}\right|_{x=-\ell_{11}}=0,\left.\frac{d y}{d x}\right|_{x=-\ell_{11}}-\left.\frac{d_{b} y_{1}}{d x}\right|_{x=-\ell_{11}}=0 \\
& \left.{ }_{s} E \cdot{ }_{s} I \frac{d^{2}{ }_{s} y}{d x^{2}}\right|_{x=-t_{u}}-\left.{ }_{b} E_{l} \dot{b}_{b} I_{l} \frac{d^{2}{ }_{b} y_{l}}{d x^{2}}\right|_{x=-\epsilon_{11}}=0 \\
& \left.{ }_{s} E \cdot \cdot_{s} I \frac{d^{3}{ }_{s} y}{d x^{3}}\right|_{x=-\ell_{11}}-\left.{ }_{b} E_{l} \cdot{ }_{b} I_{t} \frac{d^{3}{ }_{b} y_{l}}{d x^{3}}\right|_{x=-\ell_{11}}=0 \\
& \left.{ }_{s} y\right|_{x=\ell_{1},}-\left.{ }_{b} y_{r}\right|_{x=\ell_{1},}=0,\left.\frac{d y}{d x}\right|_{x=\ell_{1},}-\left.\frac{d_{b} y_{r}}{d x}\right|_{x=\ell_{1 r}}=0 \\
& \left.{ }_{s} E \cdot I \frac{d^{2}{ }_{s} y}{d x^{2}}\right|_{x=\ell_{1}}-\left.{ }_{b} E_{r} \cdot{ }_{b} I_{r} \frac{d^{2}{ }_{b} y_{r}}{d x^{2}}\right|_{x=\ell_{1},}=0 \\
& \left.{ }_{s} E_{s} I \frac{d^{3}{ }_{s} y}{d x^{3}}\right|_{x=\ell_{1}}-\left.{ }_{b} E_{r} \cdot{ }_{b} I_{r} \frac{d^{3}{ }_{b} y_{r}}{d x^{3}}\right|_{x=\ell_{1}}=0
\end{aligned}
$$

$(5 \mathrm{a}, 5 \mathrm{~b}, 5 \mathrm{c}, 5 \mathrm{~d}, 5 \mathrm{e}, 5 \mathrm{f}, 5 \mathrm{~g}, 5 \mathrm{~h}, 5 \mathrm{i}, 5 \mathrm{j}, 5 \mathrm{k}, 5 \mathrm{l})$ ここに、 $K_{l} 、 K_{r}:$ ブレース心材端部の回転剛性

$$
\ell_{2 l} 、 \ell_{2 r}: \text { ブレース心材端部無補剛区間長さ }
$$

\section{2 破䁲モードに対する耐力評価}

座屈補剛ブレースの破壊モードには、

a. 座屈補剛材の曲げ降伏（破壊モードA）

b. ブレース端部無補剛区間での、軸力とそれに伴う付加 曲げモーメントによる降伏（破墙モードB）

c. ブレース端部無補剛区間での局部座屈(破壊モードC) がある。前節の変位関数を用いて、位置 $x$ における座屈補剛ブ レースの曲げモーメントを ${ }_{b} M_{l}(x)$ (左端無補剛区間)、 ${ }_{s} M(x)$ (座 屈補剛材間)、 ${ }_{b} M_{r}(x)$ (右端無補剛区間) と表す。

破壊モードAに対して座屈補剛ブレースが健全である条件式は、 座屈補剛材の材長内の最も曲げモーメントの大きくなる位置 $x$ に対して次式で表される。

$$
{ }_{s} M_{y} z_{s} M(x) \quad\left(-\ell_{1 l} \leq x \leq \ell_{1 r}\right)
$$

ここに、, $M_{y}\left(==_{s} \sigma_{y} \cdot z\right):$ 座屈補剛材の降伏曲げモーメント

${ }_{s} \sigma_{y}:$ 座屈補剛材の降伏応力度

${ }_{s} Z:$ 座屈補剛材の弱軸の断面係数

破壊モードBに対して座屈補剛ブレースが健全である条件式は、 ブレース心材端部無補剛区間で曲げモーメントの最も大きくなる位 置 $x$ に対して次式で表される。

$$
\begin{gathered}
{ }_{b} M_{p_{l}} \geq P \cdot \frac{{ }_{b} Z_{p l}}{{ }_{b} A_{l}}+{ }_{b} M_{l}(x) \quad\left(-\frac{\ell}{2} \leq x \leq-\ell_{1 l}\right) \\
{ }_{b} M_{p_{r}} \geq P \cdot \frac{{ }_{b} Z_{p r}}{{ }_{b} A_{r}}+{ }_{b} M_{r}(x) \quad\left(\ell_{1 r} \leq x \leq \frac{\ell}{2}\right) \\
\text { ここに、 }{ }_{b} M_{p l}\left(=_{b} \sigma_{y l} \cdot Z_{p l}\right) 、{ }_{b} M_{p r}\left(==_{b} \sigma_{y r} \cdot{ }_{b} Z_{p r}\right)
\end{gathered}
$$

:ブレース心材端部無補剛区間の全塑性モーメント

${ }_{b} \sigma_{y l} 、{ }_{b} \sigma_{y r}:$ ブレース心材端部無補剛区間の降伏応力度 ${ }_{b} Z_{p l} 、{ }_{b} Z_{p r}:$ ブレース心材端部無補剛区間の弱軸の塑性 断面係数

${ }_{b} A_{l} 、{ }_{b} A_{r}:$ ブレース心材端部無補剛区間の断面積

同様に破壊モードCに対して座屈補剛ブレースが健全である条 件式は、次式で表される。

$$
\begin{array}{ll}
{ }_{b} M_{c r l} \geq P \cdot \frac{{ }_{b} Z_{p l}}{{ }_{b} A_{l}}+{ }_{b} M_{l}(x) & \left(-\frac{\ell}{2} \leq x \leq-\ell_{1 l}\right) \\
{ }_{b} M_{c r r} \geq P \cdot \frac{{ }_{b} Z_{p r}}{{ }_{b} A_{r}}+{ }_{b} M_{r}(x) & \left(\ell_{1 r} \leq x \leq \frac{\ell}{2}\right)
\end{array}
$$


ここに、 ${ }_{b} M_{c r l}\left(=_{b} \sigma_{c r t} \cdot Z_{p l}\right) 、{ }_{b} M_{c r r}\left(=_{b} \sigma_{c r r} \cdot Z_{p r r}\right)$

:ブレース心材端部無補剛区間の局部座屈モーメント

${ }_{b} \sigma_{c t r} 、{ }_{b} \sigma_{c r r}:$ ブレース心材端部無補剛区間の局部座屈応 力度

な㧍、局部座屈応力度 $\sigma_{c r}$ は単調圧縮を受けるH 形鋼の実験結果 を元にした次式により求める ${ }^{3)}$ 。

$$
\sigma_{c r}=_{b} \sigma_{y} \cdot\left\{0.6+1.6 \cdot \frac{\sigma_{y f}}{E_{b}}\left(\frac{b}{t_{f}}\right)^{2}+0.15 \cdot \frac{\sigma_{y w}}{E_{b}}\left(\frac{d}{t_{w}}\right)^{2}\right\}^{-1}
$$

ここに、 $\sigma_{y f} 、 \sigma_{y w}:$ ブレース心材端部無補剛区間のフランジと ウェブの降伏応力度

$\frac{b}{t_{f}} \cdot \frac{d}{t_{w}}:$ ブレース心材端部無補剛区間のフランジとウェ ブの幅厚比

非弾性域のブレース心材端部無補剛区間のヤング係数は、接 線係数 ${ }_{b} E_{t}$ を用いる。接線係数 ${ }_{b} E_{t}$ は、Johnson 式による座屈耐 力と接線係数による座屈耐力が等価になる次式で与える゙”。

$$
{ }_{b} E_{t}=\frac{{ }_{b} E}{0.24} \cdot\left(\frac{P}{{ }_{e} P_{y}}-\frac{P^{2}}{e^{2} P_{y}^{2}}\right) \quad\left(P>0.6_{e} P_{y}\right)
$$

ここに、, $P_{y}:$ ブレース心材端部無補剛区間の降伏軸力

ただし、座屈補剛ブレースはブレース心材全断面降伏後も、ひ ずみ硬化により耐力が上昇することから、(10) 式のヤング保数 が ${ }_{b} E / 20$ 以下となる領域では。 2)でも同梯の考え方を用いており、その妥当性は文献の中で実験値 との比較により示されている。

(6)、(7)、(8)式それぞれについて、式を満足する軸力 $P$ の最大 値は収れん計算により求まる。これは各破壊モードに対応する座 屈補剛ブレースの耐力を表しており、その最小となる值は破壊 モードと耐力を示す。但し、(7)式、(8) 式の耐力と破壊モードB、C の関係の中で、両端固定支持では耐力が (7) 式で決まるにも関わら ず破壞モードは C となる事がある ${ }^{2)}$ 。両端単純支持の場合は破壊

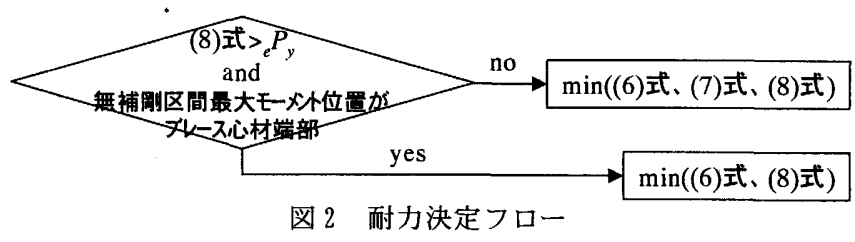

表 1 試験体パラメータ一覧

\begin{tabular}{|c|c|c|c|c|c|c|}
\hline 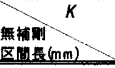 & 10 & 500 & 1,000 & \begin{tabular}{|c|} 
外 \\
想定破棲玉-1 \\
\end{tabular} & 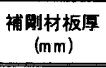 & $\begin{array}{l}\text { 試験体 } \\
\text { 端部補強 } \\
\end{array}$ \\
\hline 250 & L25L25-3 & M 25M 25-3 & $\mathrm{H} 25 \mathrm{H} 25-3$ & A & 3.2 & あり \\
\hline 500 & L50L50-4 & M $50 M 50-4$ & $\mathrm{H} 50 \mathrm{OH} 50-4$ & B & 4.5 & な \\
\hline 250 & $x$ & M 25M 25-9 & $\mathrm{H} 25 \mathrm{H} 25-9$ & c & 9 & な \\
\hline
\end{tabular}

Sシリーズ

\begin{tabular}{|c|c|c|c|c|c|}
\hline \multirow{2}{*}{ 尌䁖体名称 } & \multicolumn{2}{|c|}{ 左 } & \multicolumn{2}{|c|}{ 右 } & \multirow{2}{*}{$\begin{array}{c}\text { 補誷材板㕇 } \\
(\mathrm{mm})\end{array}$} \\
\hline & 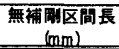 & $k$ & 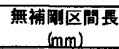 & $\kappa$ & \\
\hline H3OP $25-9$ & 300 & 1,000 & 250 & ピン & 9 \\
\hline F35P 25-9 & 350 & 固定 & 250 & ピン & 9 \\
\hline H3OF $35-4$ & 300 & 1,000 & 350 & 固定 & 4.5 \\
\hline$F 35 F 35-4$ & 350 & 固定 & 350 & 固定 & 4.5 \\
\hline
\end{tabular}

0シリーズ
モードに関わらず、耐カはブレース心材端部無補剛区間の降伏軸力 ${ }_{e} P_{y}$ を越えない”。一方、端部固定度が高くなり固定支持に近づく と、耐力はプレース心材端部無補剛区間の降伏軸力。 $P_{y}$ を越えて局 部座屈で決まる破壊モードCになる2。形断面圧縮材においても、 座屈長さが短くなると、幅厚比の大きさによっては、耐力がひずみ 硬化により降伏軸力を越えるら。ここでは、固定支持に近い境界条 件で、かつ(8) 式から求まる局部座屈で決まる耐力がブレース心材 端部無補剛区間の降伏軸力。 $P_{y}$ を越える場合、破塤モード B は起こ らないと考元、(6) 式と (8) 式から求まる耐力の小さい方の值を耐力 とする。固定支持に近い条件は、無補剛区間の最大曲げモーメント
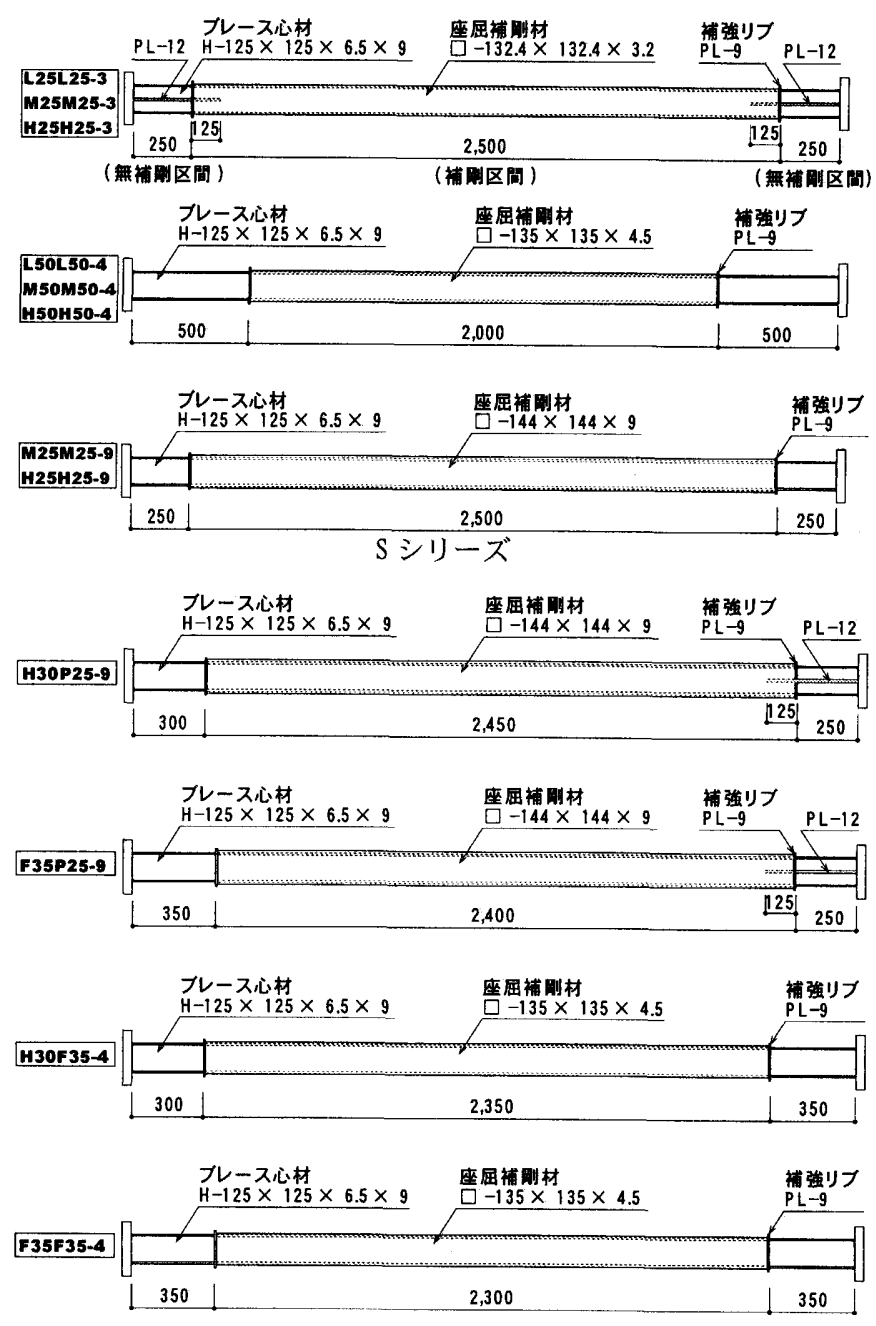

0 シリーズ
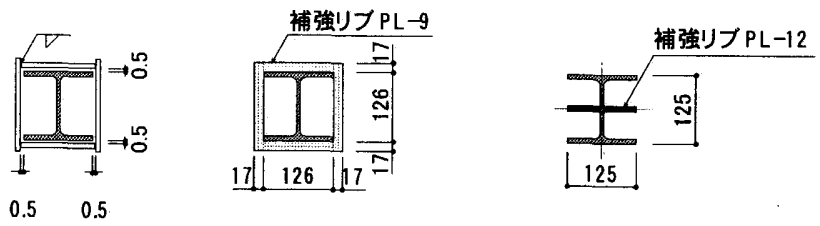

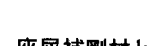

座屈補剛材と

補强リプPL-9

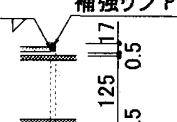

座屈補用材

2) 座屈補剛材端部

補強りフの詳細

図 3 試験体形状・法図
3) プレース心材端部

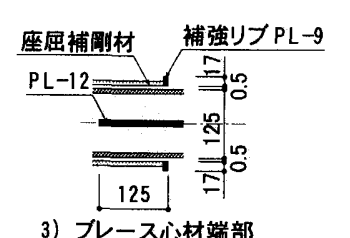


位置がブレース心材端部となる場合とした。これらの関倸を図 2 に 示す。

\section{3. 実験による耐力評価手法の妥当性検証}

\section{1 実験計画}

図 3 に試験体形状・寸法を、表 1 に試験体一覧を示す。実験は 両端で固定度が同じ $\mathrm{S}$ シリーズと固定度が異なる 0 シリーズに ついて行った。両シリーズともブレース心材にはH-125 × 125 $\times 6.5 \times 9$ を採用した。

S シリーズの試験体は座屈補剛材の曲げ降伏で耐力の決まる A タイプ（破壊モードA）、ブレース心材端部無補剛区間で軸力と 曲げモーメントによる降伏で耐力の決まる B夕イプ（破壊モード B）、局部座屈により耐力の決まるCタイプ（破壊モードC）の三 種類を設定し、それぞれの試験体に対して端部固定度 $(K=10$ 、 $500 、 1000 \mathrm{kN} \cdot \mathrm{m} / \mathrm{rad}$.) を変化させた。試験体名の L、M、H はそ れぞれ端部固定度の $K=10 、 500 、 1000 \mathrm{kN} \cdot \mathrm{m} / \mathrm{rad}$. に相当する。 0 シリーズでは、境界条件として固定支持、単純支持、半固定 支持 $(K=1000 \mathrm{kN} \cdot \mathrm{m} / \mathrm{rad}$.$) を組合わせた試験体を用意した。破$ 壊は局部座屈で耐力が決まるCタイプに設定した。なお、試験体名 の F、P、H は境界条件の固定支持、単純支持、半固定支持に相当 する。

表 2 素材の機械的性質

\begin{tabular}{|c|c|c|c|c|c|c|}
\hline 部位 & $\begin{array}{l}\text { 板席 } \\
(\mathrm{mm}) \\
\end{array}$ & $\begin{array}{l}\text { 降伏応力度 } \\
\sigma_{y}\left(\mathrm{~N} / \mathrm{m}^{2}\right)\end{array}$ & $\begin{array}{c}\text { 降伏ひずみ } \\
\varepsilon,(\mu)\end{array}$ & $\begin{array}{c}\text { 引張弹さ } \\
\sigma_{v}\left(\mathrm{~N} / \mathrm{ma}^{2}\right) \\
\end{array}$ & Y.R. & $\begin{array}{l}\text { 伸ひ } \\
e(x) \\
\end{array}$ \\
\hline 心材 & 6.5 & 303 & 1478 & 461 & 0.66 & 33.9 \\
\hline 心材フランジ & 9.0 & 281 & 1371 & 450 & 0.62 & 39.3 \\
\hline 榑䦌材 & 3.2 & 381 & 1859 & 472 & 0.81 & 31.6 \\
\hline 捕㓮材 & 4.5 & 256 & 1249 & 435 & 0.59 & 30.8 \\
\hline 㭪剛材 & 9.0 & 341 & 1663 & 494 & 0.69 & 29.4 \\
\hline 心材端部䊇強 & 12.0 & 310 & 1512 & 462 & 0.67 & 43.3 \\
\hline
\end{tabular}

図 4 に載荷装置概要を示す。端部の境界条件を単純支持にで きるテンプリン球座にPC 鋼棒を片持ち梁形式で取付け、その曲 げ剛性を利用して固定度を調整した。実測による固定度はそれ ぞれ $K=26.9 、 456 、 1180 \mathrm{kN} \cdot \mathrm{m} / \mathrm{r}$ ad. であった。加力は単調載 荷で行った。表 2 に素材の機械的性質を示す。

\section{2 実験結果}

表 3 に各試験体の破壊モードと算定耐力を示す。算定耐力内の $P_{y}$ はブレース心材中央部の降伏軸力を表し、無補剛区間のブレー ス心材に補強リブがなく、断面形状が中央と同一の場合は $P_{y}$ と (10) 式の無補剛区間のブレース心材端部の降伏軸力 $P_{e} P_{y}$ は同值とな る。写真 1 に各破壊モードの例を示す。Sシリーズの試験体は各夕 イプ毎にそれぞれ想定した破壊モードで破壊に至り、耐力が決まっ た。なお、Sシリーズ、Aタイプで $K=500 、 1000 \mathrm{kN} ・ \mathrm{~m} / \mathrm{r}$ ad.の試 験体 M25M25-3,H25H25-3 は破壊モードA である座屈補剛材の曲げ 降伏が先行したが、最終的には座屈補剛材の端部近傍のすみ肉溶接

表 3 破壊モード一覧

\begin{tabular}{|c|c|c|c|c|c|c|c|c|}
\hline \multirow[b]{2}{*}{ シリーズ } & \multirow[b]{2}{*}{ צイフ } & \multirow[b]{2}{*}{ 試験体名 } & \multicolumn{3}{|c|}{ 破棲E「” } & \multirow{2}{*}{$\begin{array}{l}\text { 破墙 } \\
\text { 端部 }\end{array}$} & \multicolumn{2}{|c|}{ 算定耐力 } \\
\hline & & & A & B & c & & $\begin{array}{c}\text { 降伏䩜力 } \\
P_{y}(\mathrm{kN})\end{array}$ & $\begin{array}{c}P_{\text {y 時の }} \\
\text { 弾性变位 } \\
\delta_{y}(\mathrm{~mm})\end{array}$ \\
\hline \multirow{8}{*}{$S$} & \multirow{3}{*}{ A } & $L 25 L 25-3$ & 01 & & & - & \multirow{8}{*}{843} & \multirow{3}{*}{4.14} \\
\hline & & $M 25 M 25-3$ & $\triangle$ & & & - & & \\
\hline & & $\mathrm{H} 25 \mathrm{H} 25-3$ & $\triangle$ & & & - & & \\
\hline & \multirow{3}{*}{ B } & $\angle 50 L 50-4$ & & O) & & - & & \multirow{5}{*}{4.19} \\
\hline & & M5OM 50-4 & & Of & & - & & \\
\hline & & $\mathrm{H} 50 \mathrm{OH} 50-4$ & & 0 & & - & & \\
\hline & \multirow{2}{*}{ C } & M25M 25-9 & & & 0 & - & & \\
\hline & & $\mathrm{H} 25 \mathrm{H} 25-9$ & & & 0 & - & & \\
\hline \multirow{4}{*}{0} & - & H3OP 25-9 & & & 0 & 半固定 & \multirow{4}{*}{843} & \multirow{2}{*}{4.16} \\
\hline & - & F35P 25-9 & & & 0 & 固定 & & \\
\hline & 5 & H30F35-4 & & & 0 & 畗定 & & \multirow{2}{*}{4.19} \\
\hline & - & F35F35-4 & & & 0 & 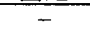 & & \\
\hline
\end{tabular}

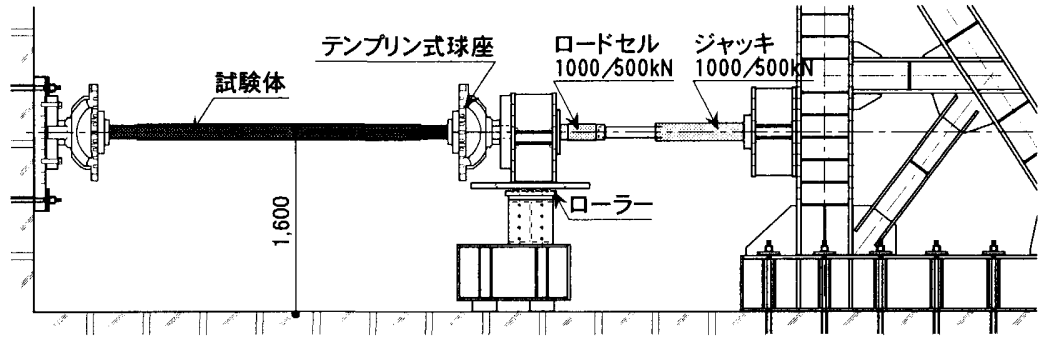

全体概要

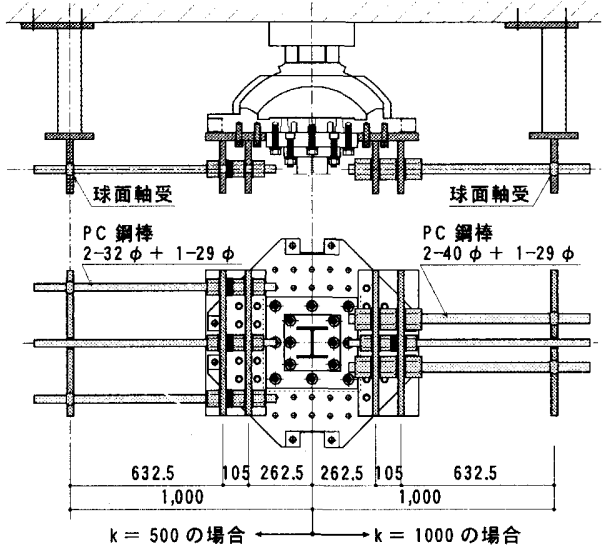

端部詳細図

図 4 載荷装置概要

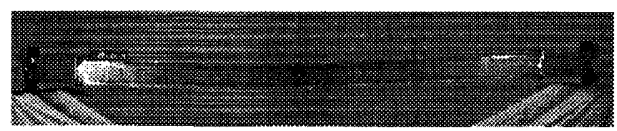

（a）破壊モードA
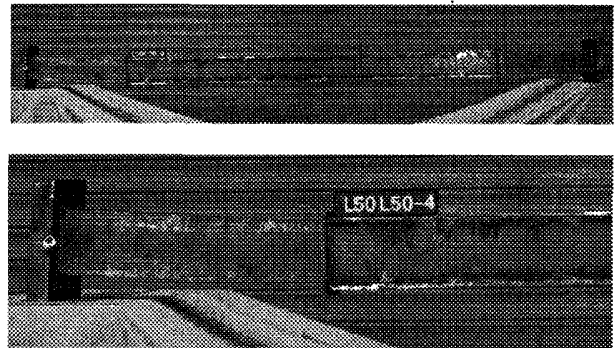

(b) 破壊モードB
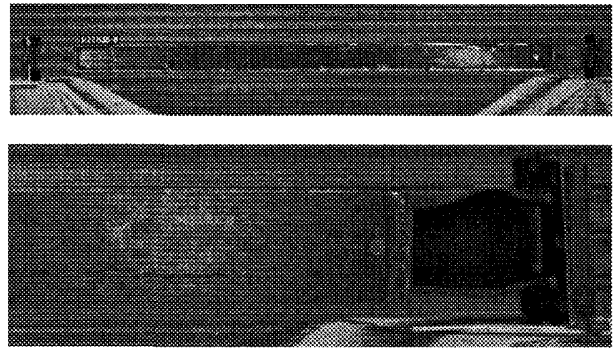

(c) 破壊モードC

写真 1 破壊状況 


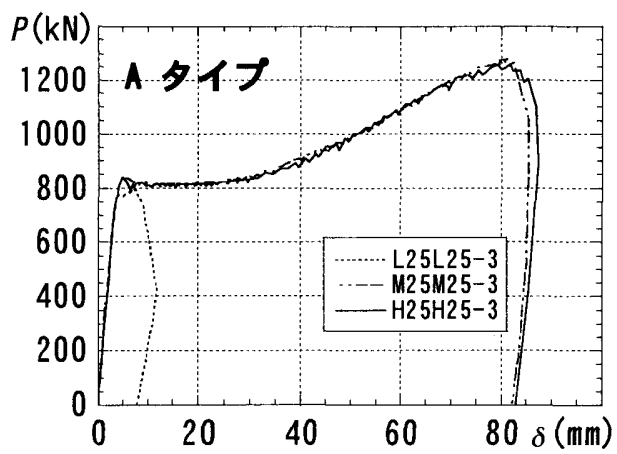

(a) $\mathrm{S}$ シリーズ(Aタイプ)

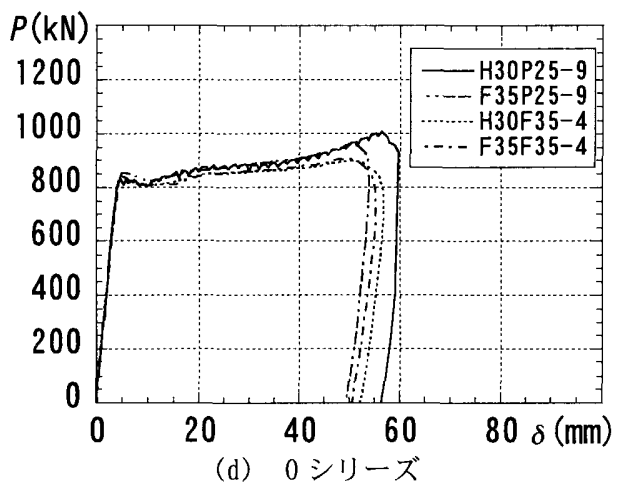

図 5 荷重 - 変位関係

の亀裂により耐力が決まった。0シリーズの試験体も、すべてブレー ス心材端部無補剛区間の局部座屈で耐力の決まる破壊モードCとな り、想定通りであった。

図 5 に各試験体の荷重 - 変位関係を示す。縦軸は軸力 $P$ を、横軸 は軸変位 $\delta$ を示す。加力は最大耐力を確認した時点で終了した。図 (a)〜 (c) に示す S シリーズでは、固定度が高くなるにつれて耐力、 変形能力共に大きくなる傾向にある。破壊モードAやCで耐力が決 まる場合には、ブレース心材の降伏軸力を越える場合が多いが、破 壊モードBの場合には越えるケースは見られない。図(d) は 0 シ リーズの関係を示す。いずれの試験体も同一の破壊モードで耐力が 決まったため、よく似た性状を示した。

図 6 に各試験体の最大耐力時のひずみ分布を示す。図中の白抜き のプロット $(O 、 \diamond 、 \triangle)$ は座屈補剛材およびブレース心材端部無補

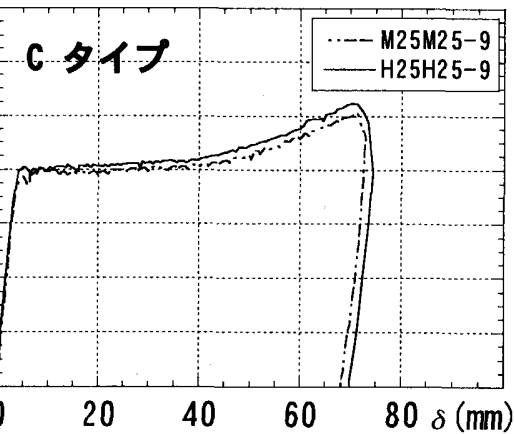

(c) $\mathrm{S}$ シリーズ(C タイプ)

剛区間の曲げひずみ分布を、また黒抜きのプロット $(\boldsymbol{O} 、 \bullet 、 \Delta)$ は ブレース心材端部無補剛区間のフランジの局部座屈ひずみを示す。 各ひずみの求め方を図 5 の挿入図に示す。Sシリーズの実験結果か ら各破壊モードの最大耐力時におけるひずみレベルは、破壊モード $\mathrm{A}$ の場合には座屈補剛材中央の曲げひずみが $1000 \mu$ 程度、破壊モ一 ドBの場合にはブレース心材端部無補剛区間の座屈補剛材との境界 部分における曲げひずみが $2500 \mu$ 程度、破壊モードCの場合にはブ レース心材端部無補剛区間フランジの座屈ひずみが 10000 $20000 \mu$ 程度と言える。ブレース心材端部無補剛区間フランジの局 部座屈により耐力が決まる場合には、ブレース心材端部無補剛区間 の曲げひずみが $1000 \mu$ に達しても耐力低下することなく、座屈ひず みに達するまで曲げ変形が進展する。0シリーズは局部座屈による 破壊を想定した試験体であり、いずれの試験体もフランジの座屈ひ ずみが卓越しているのが伺える。

\section{3 耐力評価手法の妥当性検証}

図 7 に実験結果と耐力評価結果との比較を示す。図 (a) 〜 (c) はS シリーズのもので、縦軸は耐力を、横軸はブレース端部の 固定度 (回転剛性) を示す。図中の細線は (6)、(7)、(8)式による 算定耐力を示す。初期たわみの最大值は材長の $1 / 500$ とした。図 中のプロットは実験值を表し、○、メ、ロはそれぞれ破壊モー ド A、B、Cに相当する。図(a)のは座屈補剛材の端部近傍の すみ肉溶接の亀裂による破壊を表す。

図 2 のフローによる耐力を、太い破線で示す。図(a)では固定度 に関わらず破壊モードAで耐力が決まっている。また、図(b)〜 (c)
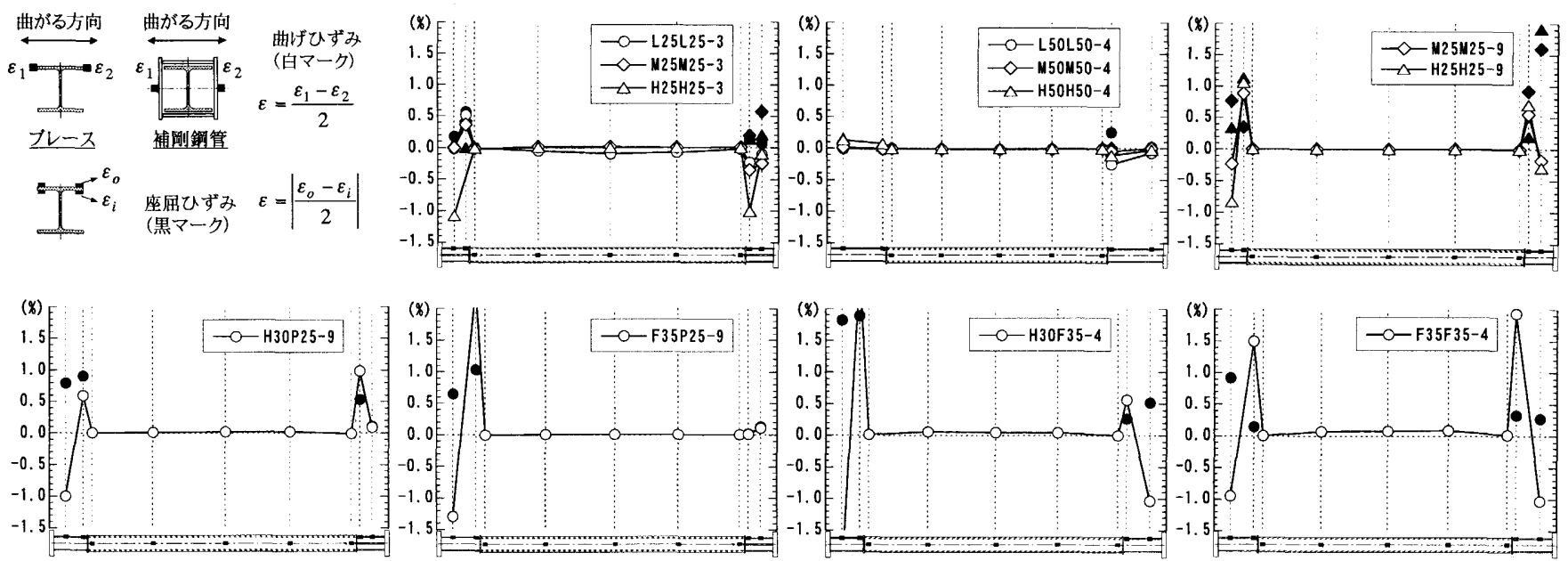

図 6 最大耐力時のひずみ分布 


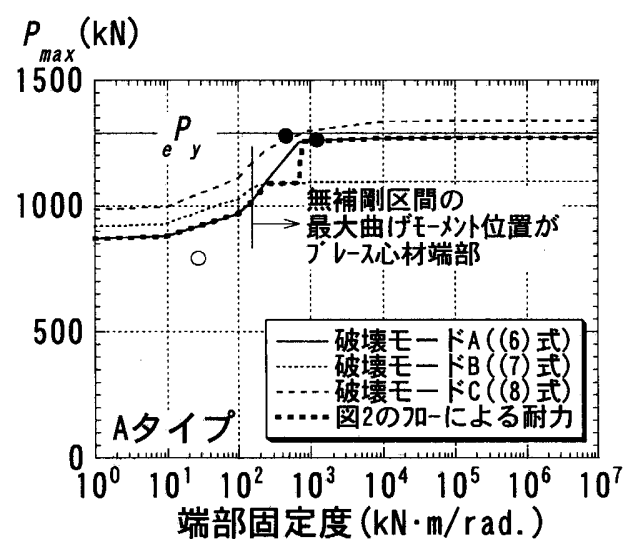

(a) $S$ シリーズ(A タイプ)

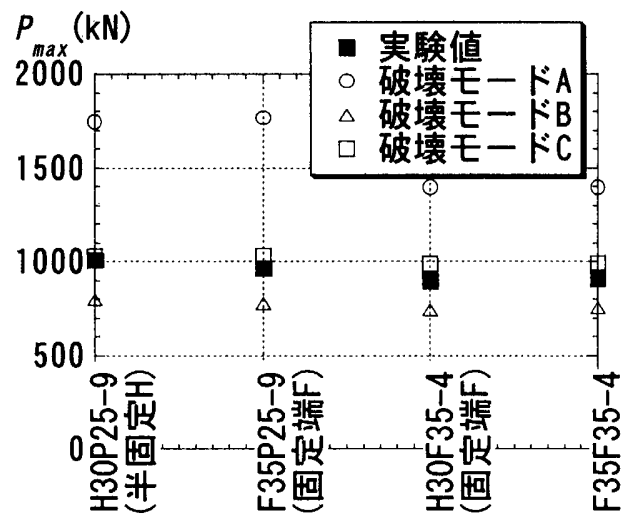

(d) 0 シリーズ

図 7 算定耐力と実験結果の比較

では、固定度が高くなるにつれて、破壊モードBから破壊モードC へと移行している。図(c)では、破壊モ一ド B の耐力より、破埢 モードCの耐力が高い場合でも、破壊モードCで耐力が決ってい る。いずれのタイプの試験体も、破壊モードと算定耐力が良い 対応を示しており、図 2 のフローによる耐力の評価が適切である と言える。

固定度が単純支持あるいは固定支持と見なせると判断する尺度と しては、評価耐力の変動が小さくなる剛性を把握すればよい。例え ば、今回設定した試験体では、破壊モードAで耐力が決まる場合、

(6) 式から判断して、 $K=10 \mathrm{kN} \cdot \mathrm{m} / \mathrm{rad}$. 以下の回転剛性では単純 支持と、 $K=10000 \mathrm{kN} \cdot \mathrm{m} / \mathrm{rad}$. 以上の回転剛性では固定支持と同 等の境界条件になっていると言える。一方、破壊モ一ドB、Cで耐 力が決まる場合は、破壊モード B の耐力を示す（7) 式では固定度に 対する感度が悪いため、判断が難しい。このような場合は、破壊 モードAの（6)式と破壊モードCの（9）式から判断することになる。

図（d）慣端で固定度の異なる試験体 0 シリーズの結果を示 す。両端で固定度が異なる場合に関しても、破壊モードCで壊れ た実験値と破壊モードCの計算值は良い対応を示しており、耐力 評価の妥当性が伺える。

\section{4. 実建物詳細の固定度について}

ここでは、実建物に用いられている詳細がどの程度の固定度を有 しているかを検討する。図 8 に対象とするブレース詳細を示す。架 構に対してハの字に取り付く座屈補剛ブレースを対象とした。柱一 梁接合部に取り付く端部は固定と推定されるため、梁側の端部に関

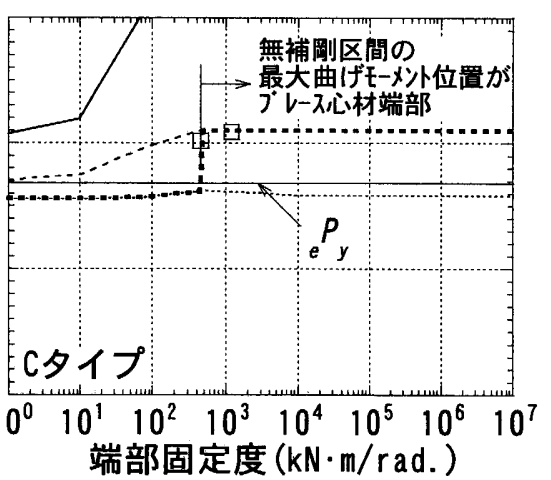

(c) $\mathrm{S}$ シリーズ(C タイプ)

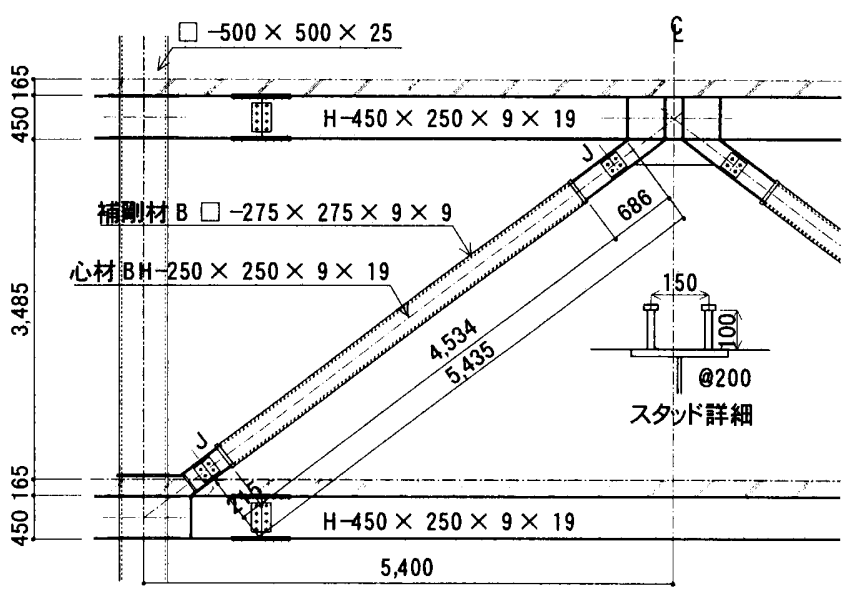

図 8 ブレース詳細

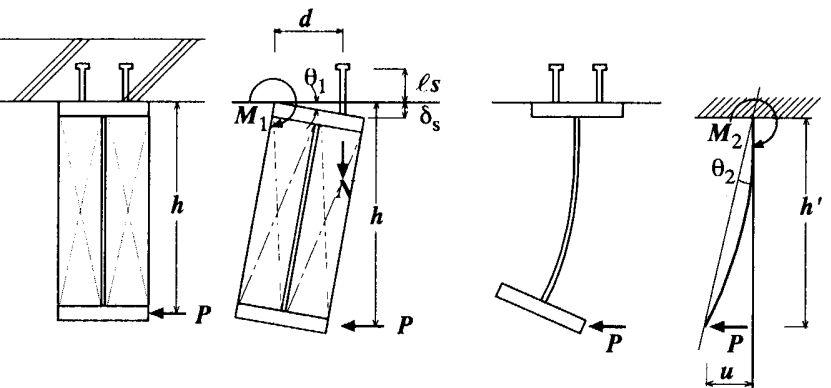

(a) スタッドの抜け出し

(b) ウェブの面外変形
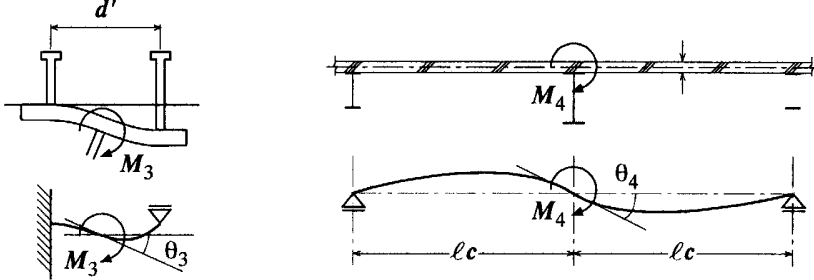

（d） スラブの曲げ剛性

(c) フランジの面外変形

図 9 接合部回転剛性検討モデル

して検討する。梁側端部の固定度は回転剛性として考え、文献 6) 〜9)に基づきスタッドの抜け出し、ウェブの面外変形、フランジ の面外変形、スラブの面外剛性を考慮して求める (図 9 参照)。ス タッドの抜け出しに対する回転剛性 $K_{1}$ は次のように求められる。

$$
K_{1}=\frac{n_{e} \cdot A_{s} \cdot E_{s} \cdot d^{2}}{\ell_{s}}
$$

ここに、 $n_{e}:$ 有効幅中のスタッド本数の $1 / 2$ 


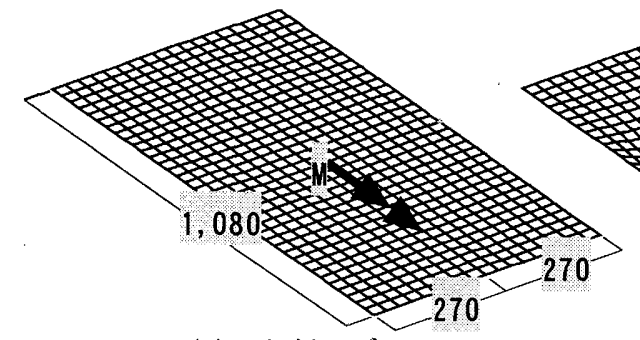

(a) 解析モデル

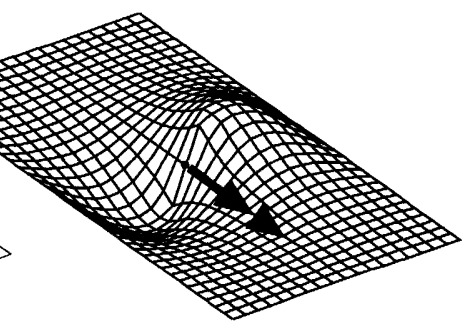

(b) 変形図

図 10 有効幅の検討解析モデル

$A_{s} 、 E_{s} 、 \ell_{s}:$ スタッドの断面積、ヤング係数、長さ $d:$ 回転中心からスタッドまでの距離

ウェブの面外変形に対する回転剛性 $K_{2}$ は次のように求められる。

$$
K_{2}=\frac{3 \cdot E_{w} \cdot I_{w}}{h^{\prime}}
$$

ここに、 $E_{w} \cdot I_{w}$ : 有効幅を考慮したウェブの面外曲げ剛性

$$
h^{\prime}=H-1.5 \cdot t_{f}
$$

$H: t_{f}:$ 梁成、フランジ板厚

フランジの面外変形に対する回転剛性 $K_{3}$ は次のように求められる。

$$
K_{3}=\frac{16 \cdot E_{f} \cdot I_{f}}{d^{\prime}}
$$

ここに、 $E_{f} \cdot I_{f}$ : 有効幅を考慮したウェブの面外曲げ剛性

$$
d^{\prime}: \text { スタッドの距離 }
$$

スラブの面外変形に対する回転剛性 $K_{4}$ は次のように求められる。

$$
\begin{gathered}
\left.K_{4}=\frac{12 \cdot E_{c} \cdot I_{c}}{\ell_{c}} \text { (両側スラブの場合 }\right) \\
K_{4}=\frac{3 \cdot E_{c} \cdot I_{c}}{\ell_{c}} \text { (片側スラブの場合) }
\end{gathered}
$$

ここに、 $E_{c} \cdot I_{c}$ : 有効幅を考慮したスラブの面外曲げ剛性

$$
\ell_{c}: \text { スラブのスパン }
$$

以上の回転剛性をすべて考慮した回転剛性 $K_{\theta}$ は次式で表される。

$$
K_{\theta}=1 / \sum_{i=1}^{4}\left(1 / K_{i}\right)
$$

今回、梁接合部にはウェブの曲げ変形を拘束するスティフナーが 設けられているため、ウェブの面外変形は考慮しないものとした。 鋼種はすべて $490 \mathrm{~N} / \mathrm{mm}^{2}$ クラスである。スラブは $F_{c}=24 \mathrm{~N} / \mathrm{mm}^{2}$ $\left(E_{c}=23000 \mathrm{~N} / \mathrm{mm}^{2}\right)$ の両側スラブである。(11) (15) 式の有効幅は図 10 に示す有限要素法による弾性解析に基づき求めた。スラブの解 析モデルは長さを梁スパン $10,800 \mathrm{~m} \mathrm{~m}$ 、幅を梁ピッチ $\ell_{c}$ $(=2,700 \mathrm{~mm}) の 2$ 倍の板要素とした。スラブ中央の節点に曲げモー メントを作用させ、両端単純支持材の中央に同じ曲げモーメントを 作用させた場合と作用点の回転角が一致するのに必要な幅を有効幅 とする。本ケースでは $1,013 \mathrm{~mm}$ であった。図 11 に梁側端部固定度 と座屈補剛ブレースの耐力との関倸および計算結果を示す。本詳細 は概ね固定支持と見なせる固定度を有していることがわかる。な お、引張力を受けるもう一方の座屈補剛ブレースは梁の回転を拘束 するため、実際には計算した回転剛性より高い剛性になると考えら れる。

\section{5. おわりに}

端部に無補剛区間を有する座屈補剛 H 形鋼ブレースを対象に、端

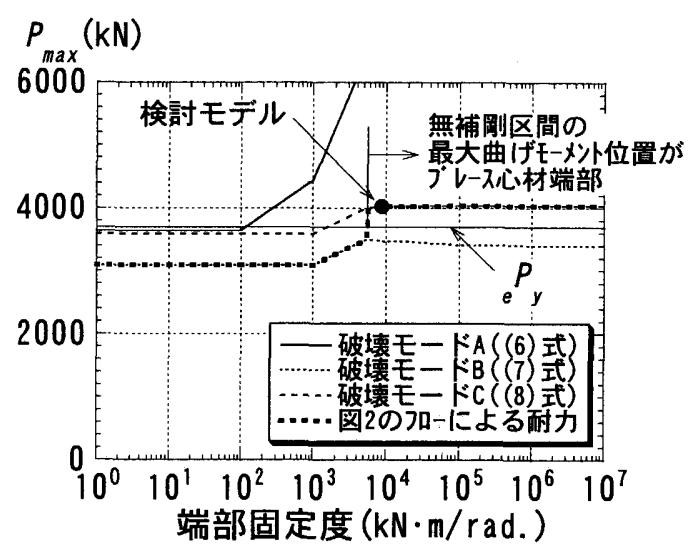

図 11 座屈補剛ブレースの耐力と端部固定度の関係

部固定度が耐力に与える影響の把握と提案した耐力評価式の妥当性 を示すことを目的に端部固定度をパラメータとした構造実験を行っ た。また、実建物の端部固定度の評価を行った。以下に得られた成 果を示す。

1）座屈補剛ブレースの破壊モードには、座屈補剛材の曲げ 降伏、ブレース端部無補剛区間での軸力とそれに伴う付加 曲げモーメントによる降伏、ブレース端部無補剛区間での 局部座屈の三種類があり、それぞれの破壊モードに対して耐 力評価式を提案した。

2）構造実験において、両端の固定度を同じとした試験体では、 三種類の破壊モードが見られた。提案した耐力評価式は、座 屈補剛ブレースの破壊モ一ドに対する耐力を精度良く捉えて おり、その妥当性が確認された。

3）両端で固定度を変えた試験体については、破壊モードがブ レース端部無補剛区間での局部座屈であったが、この場合 も耐力評価式が精度良く耐力を捉えており、その妥当性が確 認された。

4）実建物の端部接合部詳細に対して固定度の評価方法の一例を 示し、実建物に用いられるブレースに対して端部固定度の評 価を行った。当該ブレースについては、梁側の詳細は概ね固 定支持と見なせる固定度を有したものであった。

\section{〈参考文献〉}

1）宇佐美徹、金子 洋文: 禹端部に無補岡区間を有する座屈補剛H 形鋼ブレースの耐力について 一両端単純支持一、日本建築学会構 造系論文集、第 542 号、pp.171-177、2001.4

2）宇佐美 徹、金子 洋文、小野徹郎: 両端部に無補岡区間を有す る座同補剛H形鍓ブレースの酎力について 一両端固定支持一、日 本建築学会構造系論文集、第 558号、pp.211-218、2002.8

3) 吳 榮錫、加藤 勉: H形銅断面銅構造部材の塑性局部座屈之変形能 力、日本建築学会構造工学論文集、Vol.34B、1988.4

4) Hans H. Bleich:Buckling Strength of Metal Structures, MCGRAT-HILL BOOK COMPANY, 1952

5）日本建築学会:践構造座屈設計指針、丸善1996.1

6）高橋 賢司、他4名:鉄骨梁の横座屈挙動に及ぼすスラブ拘束効果に関 する研究、1992 年度大会 (北陸) 学術講演梗概集 C 分囘、pp1139$1140 、 1992.8$

7）八木 毅、他5名:鉄骨梁の横座届挙動に及ぼすスラブ拘束効果に関す る研究(その2 細長比の影響)、1993年度大会(関東) 学術講演梗概集 C 分冊、pp1451-1452、1993.7

8）谷口 元、他6名:鉄骨梁の横座屈挙動に及ぼすスラブ拘束効果に関す 
る研究 (その3 スラプの固定度)、1994年度大会 (東海) 学術講演梗概 集 C 分冊、pp1125-1126、1994.7

9）宇佐美 徹、他6名:鉄骨梁の横座用挙動に及ぼすスラブ拘束効果に関 する研究 (その4 ウェブ幅厚比の影響)、1994年度大会 (東海)学術講 演梗概集 C 分冊、pp1127-1128、1994.?

付録 1

以下に、(11)〜 (15) 式の求め方を示す。なお、記号は図 9 参照の こと。

スタッドの拔け出しに対する回転剛性 $K_{1}$ は、

$K_{1}=M_{1} / \theta_{1}$

で求められ、これに(付 2)〜 (付 4) 式を代入することで(11) 式が求 まる。

$M_{1}=n_{e} \cdot N \cdot d$

$\theta_{1}=\delta_{s} / d$

(付 3)

$\delta_{s}=\frac{N \cdot \ell_{s}}{A_{s} \cdot E_{s}}$

ここに、 $N$ : スタッド一本に作用する軸力

ウェブの面外変形に対する回転剛性 $K_{2}$ は、

$$
K_{2}=M_{2} / \theta_{2}
$$

で求められ、これに(付 6)〜（付 8) 式を代入することで(12) 式が求 まる。

$$
\begin{aligned}
& M_{2}=P \cdot h^{\prime} \\
& \theta_{2}=u / h^{\prime} \\
& u=\frac{P \cdot h^{\prime 3}}{3 \cdot E_{w} \cdot I_{w}}
\end{aligned}
$$

フランジの面外変形に対する回転剛性 $K_{3}$ は、

$$
K_{3}=M_{3} / \theta_{3}
$$

で求められ、これに(付 10$)$ 式を代入することで(13) 式が求まる。

$$
\theta_{3}=\frac{M_{3} \cdot d^{\prime}}{16 \cdot E_{f} \cdot I_{f}}
$$

スラブの面外変形に対する回転剛性 $K_{4}$ は、

$$
K_{4}=M_{4} / \theta_{4}
$$

で求められ、これに(付 12) （付 13) 式を代入することで (14)〜 (15) 式が求まる。

$$
\begin{aligned}
& \left.\theta_{4}=\frac{M_{4} \cdot \ell_{c}}{12 \cdot E_{c} \cdot I_{c}} \text { (両側スラブの場合 }\right) \\
& \left.\theta_{4}=\frac{M_{4} \cdot \ell_{c}}{3 \cdot E_{c} \cdot I_{c}} \text { (片側スラブの場合 }\right)
\end{aligned}
$$

